\title{
Respiratory System Symptoms in the Neighborhood of a Wastewater Treatment Plant
}

\author{
Aleksandra Jaremków ${ }^{1 *}$, Leszek Noga², Krystyna Pawlas ${ }^{1,3}$ \\ ${ }^{1}$ Department of Hygiene, Wroclaw Medical University, J. Mikulicza-Radeckiego 7, 50-368 Wroclaw, Poland \\ ${ }^{2}$ Department of Pathophysiology, Wroclaw Medical University, Marcinkowskiego 1, 50-368 Wroclaw, Poland \\ ${ }^{3}$ Institute of Occupational Medicine and Environmental Health, 13 Kościelna, 41-200 Sosnowiec, Poland
}

Received: 17 March 2017

Accepted: 26 May 2017

\begin{abstract}
The aim of our study was to assess the incidence of respiratory system disorders among residents in the neighborhood of a wastewater treatment plant compared to the population living outside the impact area. We conducted a questionnaire survey on two populations: one from the vicinity of the wastewater treatment plant (586 people) and another from a village located far away from the plant ( 502 people). Studied populations were also divided according to place of residence and distance from the plant: zones A, B, C. Survey questions concerned the respiratory system symptoms and housing conditions. Respondents from the exposed group reported the following symptoms more often than the control group: frequent colds, recurrent respiratory tract infections, throat irritation, dyspnoea, recurrent rhinitis, and nasal irritation/ burning sensation. Among the risk factors for respiratory disorders, significant were: living in blocks of flats $(\mathrm{OR}=1.78$; CI 1.13-2.81), air pollution by odours ( $\mathrm{OR}=1.64$; CI 1.04-2.56), period of residence $(\mathrm{OR}=1.02$; CI 1.00-1.03) and age of respondents $(\mathrm{OR}=0.98$; CI 0.97-0.98), while the ownership of pets had a protective effect $(\mathrm{OR}<1)$. Reported symptoms were also associated with air pollution by staphylococci $(\mathrm{OR} \sim 5)$. The obtained results show that proximity to a wastewater treatment plant deteriorates the health of nearby residents.
\end{abstract}

Keywords: environmental exposure, health, respiratory tract diseases, wastewater

\section{Introduction}

Municipal wastewater contains various chemicals and biological factors, including pathogens (e.g., Escherichia coli, Salmonella, Shigella). Chemical agents - and in particular their organic components are perceived primarily as unpleasant odours and are

*e-mail: aleksandrajaremkow@wp.pl a troublesome aspect of this type of facilities. As for biological factors, they may be emitted to the environment in the form of a bioaerosol during the treatment process. A bioaerosol contains microorganisms, their fragments, metabolites, and exo- and endotoxins dispersed in the air in droplet form. Depending on weather conditions and wind strength, they may disperse outside the wastewater treatment plant [1]. Consequently, they constitute a health risk to the employees as well as residents in the neighbourhood of such plants, and especially to people 
with immunological dysfunctions. Depending on their size, they penetrate the relevant sections of the respiratory system. The smaller the particles, the deeper they get (where the defence mechanisms are weaker), so the particles can initiate inflammatory reactions. This can result in the appearance of the following symptoms of the respiratory system: respiratory tract infections, coughing, bronchitis, dyspnoea [2].

Numerous articles have already dealt with occupational exposure and health effects among employees in wastewater treatment plants [3-5] and composting plants [6-7]. On the other hand, there are only a few published studies on the impact of such plants on the health of local populations (e.g., Aatamila [8] and Herr [9]). In our previous article [10] we demonstrated that living in the vicinity of a wastewater treatment plant contributes to the occurrence of gastrointestinal symptoms among local inhabitants.

The purpose of this work is to assess the incidence of disorders of the respiratory system among populations living in the surroundings of the studied wastewater treatment plant compared to the control group outside the impact area.

\section{Material and Methods}

\section{Survey Research}

We prepared an original questionnaire by suitably modifying the questionnaire used in CESAR studies [11]. The survey questions concerned current symptoms and medical conditions of the respiratory system (e.g., frequent colds, recurrent respiratory tract infections, throat irritation, dyspnoea, recurrent rhinitis, nasal irritation/burning sensation, recurrent sinusitis, chronic cough, bronchial asthma) that may result from exposure to pollutants emitted from the studied mechanicalbiological wastewater treatment plant (block diagram in Fig. 1). The respondents could choose from three possible answers: "Yes, my opinion" (disorders suffered by the respondent but undiagnosed by a doctor), "Yes, doctor's opinion" (disorders diagnosed by a doctor), and "No." Other questions included in the survey concerned respondent's background (age, sex, education), housing conditions, and other factors that may affect the health of the inhabitants (period of residence, character of building, exposure to tobacco smoke at home, using a gas stove, type of heating, dampness in the flat, ownership of pets, exposure to car fumes).

The survey covered two groups of people: one of which lived in the neighbourhood of the treatment plant while the other consisted of residents of the same commune but living outside the impact area of the plant. Such selection of the control group and the exposed group from adjacent areas ensured similar social and cultural conditions (health and eating habits) and similar weather and climate conditions among the compared populations. Analyzed areas were inhabited by approximately 5,000 people in the village outside the impact area of the wastewater treatment plant and approximately 11,000 people in the area of exposure. Taking into account the number of inhabitants as well as their age structure (approximately 5\% children aged 3-10 years and approximately $80 \%$ adults), we calculated that sample sizes should count 590 and 504 persons in the exposed and control groups, respectively. Selection into groups was based on systematic sampling. The sampling frame consisted of residential buildings located in the area of the analysed municipalities, in which the interviewers visited every tenth flat according to the address list (from the local municipal office). The questionnaire survey was conducted using the face-to-face method.

Based on microbiological and olfactometric measurements performed by the the Faculty of Environmental Engineering of Wroclaw University of Technology, we designated the impact area of the studied wastewater treatment plant. Microbiological measurements covered an area $0.5 \mathrm{~km}$ from the plant, while olfactometric measurements were to $1.5 \mathrm{~km}$ east of the wastewater treatment plant and $2.5 \mathrm{~km}$ northwest of the plant.

The impact area of the studied wastewater treatment plant reached up to approximately $1.5 \mathrm{~km}$ from the plant (where the strongest pollution was up to approximately $0.5 \mathrm{~km}$ from the plant). On this basis, the area around the plant was divided into three zones: A, B, and C (Table 1). Zone A covered the area up to approximately $0.5 \mathrm{~km}$ from the wastewater treatment plant (strong microbiological pollution - especially staphylococci and the highest incidence of odours, up to $92 \%$; most-exposed residents). Zone B $(0.5 \mathrm{~km}$ to $1.5 \mathrm{~km}$ from the wastewater treatment plant) was an intermediate zone between zones $\mathrm{A}$ and

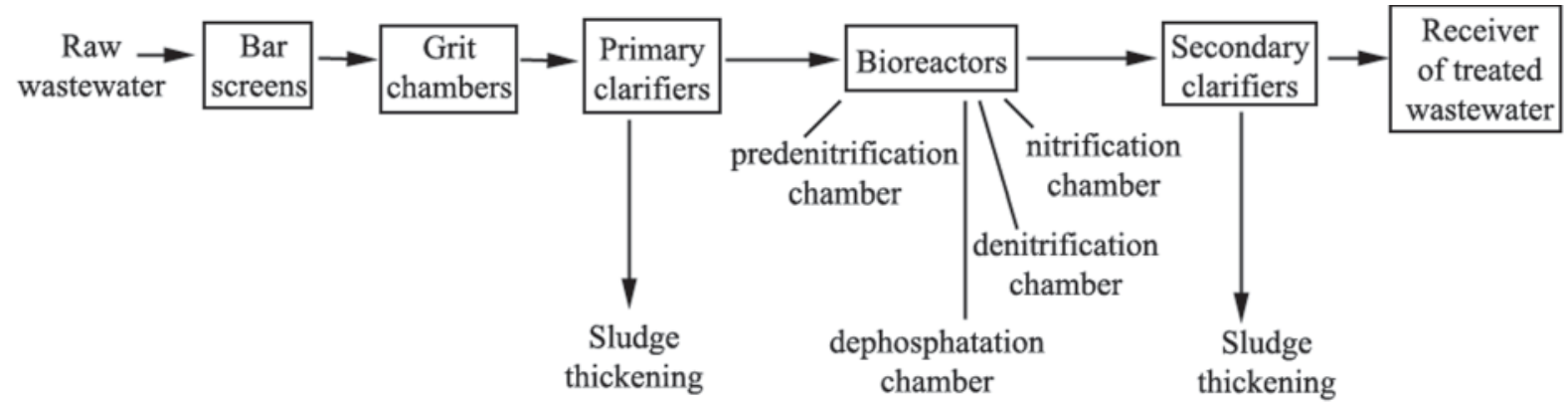

Fig. 1. Block diagram of the studied wastewater treatment plant; ADF about 100,000 m³/day; PE about 1,000,000. 
Table 1. Characteristics of air pollution around the wastewater treatment plant.

\begin{tabular}{|c|c|c|c|}
\hline & Air pollutants & Range & $\begin{array}{c}\text { Zones: } \\
\text { A }(<0.5 \mathrm{~km}) \\
\mathrm{B}(0.5-1.5 \mathrm{~km}) \\
\mathrm{C}(>2 \mathrm{~km})\end{array}$ \\
\hline \multirow{8}{*}{$\begin{array}{l}\text { Concentration } \\
{\left[\mathrm{CFU} / \mathrm{m}^{3}\right]}\end{array}$} & psychrofilic and mesofilic bacteria & 52 & A \\
\hline & actinomycetes & $0-183$ & A \\
\hline & $\alpha$-haemolytic staphylococci & $26-826$ & A \\
\hline & $\beta$-haemolytic staphylococci & $0-1180$ & A \\
\hline & mannitol-positive staphylococci & $0-288$ & A \\
\hline & mannitol-negative staphylococci & $0-354$ & A \\
\hline & moulds & $217-9432$ & A \\
\hline & yeast-like fungi & $0-524$ & A \\
\hline \multirow{3}{*}{ Incidence $[\%]$} & odours in summer (S) and in winter (W) & $\begin{array}{l}25-92(\mathrm{~S}) \\
0-68(\mathrm{~W})\end{array}$ & A \\
\hline & odours in summer (S) and in winter (W) & $\begin{array}{l}0-78(\mathrm{~S}) \\
0-33(\mathrm{~W})\end{array}$ & $\mathrm{B}$ \\
\hline & odours in summer (S) and in winter (W) & $\begin{array}{c}0-33(\mathrm{~S}) \\
0-21(\mathrm{~W})\end{array}$ & $\mathrm{C}$ \\
\hline
\end{tabular}

CFU - colony-forming unit.

zone $\mathrm{C}$ (medium exposure - the incidence of odours from 0 to $78 \%$ at the boundary with zone A). Zone $\mathrm{C}$ consisted of people from the control group living in the area more than $2 \mathrm{~km}$ from the plant, where the incidence of odours does not exceed $33 \%$. The details on air pollution are described in [10]. The respondents and interviewers at the time of collecting questionnaires did not know the zone membership (zone division was made after collecting all questionnaires).

The populations were divided into subgroups: adults aged 20 to 65 and children aged 3 to 10 (on behalf of the children; answers were provided by parents/legal guardians). Teenagers and people over 65 years old were excluded from the analysis due to the unique health aspects of those groups that could have introduced additional confounders (health changes resulting from adolescence, senile diseases).

The survey examined 1,088 out of 1,094 people from both municipalities (six people did not meet the age criteria). There were 586 completed questionnaires from the exposed group and 502 from the control group.

Free and informed consent of the participants or their legal representatives was obtained. The study was approved by the Bioethics Committee of Wroclaw Medical University, Poland (approval No. KB 764/2012).

\section{Statistical Analysis}

Statistical analysis was performed using Statistica 10.0 PL. Disorders of the respiratory system in respondents were compared between the control and the exposed groups (and in different distance zones: A, B, C) for both adults and children. We conducted Pearson's chi-squared test. In order to assess the impact of risk factors on the occurrence of respiratory disorders (confirmed by medical opinion), we performed a logistical regression analysis (single-factor models and multi-factor models). Single-factor models were used to assess the impact of individual microorganisms (concentrations exceeding Polish standards [12-13] (Table 2) and odours on the symptoms of the respiratory system, while multifactor models analysed the impact of different comorbid potential health risk factors. The first multi-factor model included all respondents. The second model compared the incidence of these disorders only among the residents of the zone nearest to the studied wastewater treatment plant and the control group. This model contained an additional risk factor - the coexistence of microorganisms and odours. Risk factors included: place of residence in the vicinity of the wastewater treatment plant, sex, age, period of residence, character of building (e.g., living in block of flats), exposure to tobacco smoke at home, using a gas stove, type of heating (e.g., central heating), the presence of dampness in the flat (e.g., often or all the time), ownership of pets, exposure to car fumes (often or all the time), air pollution of odours (incidence of odours). We calculated the odds ratios $(\mathrm{OR} ; \mathrm{OR}>1$ - existence of a risk) and confidence intervals (CI) according to the equations [14]:

$$
\begin{gathered}
O R=\frac{a d}{b c} \\
95 \% C I=\operatorname{Exp}\left[\ln O R \pm 1.96+\sqrt{\left.\frac{1}{a}+\frac{1}{b}+\frac{1}{c}+\frac{1}{d}\right]}\right.
\end{gathered}
$$


Table 2. Polish standards of microbiological air pollution.

\begin{tabular}{|c|c|c|c|c|c|c|}
\hline \multirow{4}{*}{$\begin{array}{c}\text { Total number } \\
\text { of bacteria } \\
{\left[\mathrm{CFU} / \mathrm{m}^{3}\right]}\end{array}$} & \multicolumn{4}{|c|}{ Number of microorganisms $\left[\mathrm{CFU} / \mathrm{m}^{3}\right]$} & \multirow{2}{*}{\multicolumn{2}{|c|}{ Degree of air pollution }} \\
\hline & \multirow{3}{*}{ actinomycetes } & \multicolumn{2}{|c|}{ staphylococci } & \multirow{3}{*}{ moulds } & & \\
\hline & & $\begin{array}{c}\alpha- \\
\text { haemolytic }\end{array}$ & $\begin{array}{c}\beta- \\
\text { haemolytic }\end{array}$ & & \multirow{2}{*}{ by bacteria } & \multirow{2}{*}{ by moulds } \\
\hline & & mannitol $(+)$ & mannitol(-) & & & \\
\hline$<10^{3}$ & $<10$ & lack & lack & $3 \cdot 10^{3}-5 \cdot 10^{3}$ & no pollution & $\begin{array}{l}\text { average clean atmospheric air, especially } \\
\text { in late spring and early autumn }\end{array}$ \\
\hline $10^{3}-3 \cdot 10^{3}$ & $10-10^{2}$ & $\leq 25$ & $\leq 50$ & $5 \cdot 10^{3}-10^{4}$ & $\begin{array}{l}\text { average } \\
\text { pollution }\end{array}$ & $\begin{array}{c}\text { pollution that may adversely affect the } \\
\text { human environment }\end{array}$ \\
\hline$>3 \cdot 10^{3}$ & $>10^{2}$ & $>25$ & $>50$ & $>10^{4}$ & $\begin{array}{l}\text { strong } \\
\text { pollution }\end{array}$ & $\begin{array}{c}\text { pollution posing threat to the human } \\
\text { environment }\end{array}$ \\
\hline
\end{tabular}

...where $a$ is the number of people with both respiratory system symptoms and exposure to the risk factor, $b$ is the number of people with exposure to the risk factor but without respiratory system symptoms, $C$ is the number of people with respiratory system symptoms but without exposure to the risk factor, and $d$ is the number of people without respiratory system symptoms and without exposure to the risk factor. Letter symbols $a, b, c$, and $d$ correspond to marks of the typical contingency table $(2 \times 2)$ used in studies on disease and exposure status. The adopted level of statistical significance was $\mathrm{p}<0.05$.

\section{Results \\ DemographicAnalysis of the Studied Populations}

Tables 3 and 4 show the characteristics of the respondents (children and adults) from the impact area of the wastewater treatment plant and of the control group. The structural distributions of the two populations are not significantly different in terms of age and sex. In the exposed and control groups children account for $28.8 \%$ and $25.5 \%$, respectively, while adults account for $71.2 \%$ and $74.5 \%$, respectively. Both groups have a similar number of men and women in almost equal proportions. After the division into zones of residence depending on the distance from the wastewater treatment plant, the children accounted for: $49.4 \%$ (in zone A), $25.3 \%$ (in zone B), and $25.5 \%$ (in zone C), while adults were $50.6 \%, 74.7 \%$, and $74.5 \%$, respectively. In all groups the average age was $6.07(\mathrm{SD}=2.54)$ for children and 42.34 $(\mathrm{SD}=12.80)$ for adults. The period of residence in the analysed municipalities was similar in the case of children: approximately 5 years and in the case of adults it ranged from 12 years in zone B to 18 years in zone $\mathrm{C}$. In each group the majority of people were adults with a secondary education $(76 \%)$.

A majority people from the exposed group lived in blocks of flats and used central heating, in contrast to the people from the control group, who lived in detached houses with other sources of heating (e.g., coal stove or fireplace). Significant differences between the exposed and the control groups concerned exposure to tobacco smoke in the flat, ownership of pets, and using a gas stove. In the exposed group, the percentage of people exposed to tobacco smoke was: $22.6 \%$ (children) and $35.0 \%$ (adults), and in the control group $16.4 \%$ (children) and $18.5 \%$ (adults). The owners of pets and cooker users were mostly people from the control group. Exposure to car fumes and the presence of dampness in the flats were comparable in both populations with no significant differences between them.

Table 3. Characteristics of children (3-10 years) in the study population.

\begin{tabular}{|c|c|c|}
\hline Characteristic & $\begin{array}{c}\text { Control } \\
\left(\mathrm{n}^{*}=128\right)\end{array}$ & $\begin{array}{c}\text { Exposed } \\
\left(\mathrm{n}^{* *}=169\right)\end{array}$ \\
\hline Male & $\begin{array}{c}56 \\
(43.8 \%)\end{array}$ & $\begin{array}{c}89 \\
(52.7 \%)\end{array}$ \\
\hline Female & $\begin{array}{c}72 \\
(56.2 \%)\end{array}$ & $\begin{array}{c}80 \\
(47.3 \%)\end{array}$ \\
\hline $\begin{array}{c}\text { Age } \\
\text { 3-6 years }\end{array}$ & $\begin{array}{c}71 \\
(14.1 \%)\end{array}$ & $\begin{array}{c}94 \\
(16.0 \%)\end{array}$ \\
\hline $7-10$ years & $\begin{array}{c}57 \\
(11.4 \%)\end{array}$ & $\begin{array}{c}75 \\
(12.8 \%)\end{array}$ \\
\hline Living in blocks of flats & $\begin{array}{c}17 \\
(13.3 \%)\end{array}$ & $\begin{array}{c}150 \\
(88.8 \%)\end{array}$ \\
\hline Heating - central heating & $\begin{array}{c}69 \\
(53.9 \%)\end{array}$ & $\begin{array}{c}167 \\
(98.8 \%)\end{array}$ \\
\hline Using a gas stove & $\begin{array}{c}115 \\
(89.8 \%)\end{array}$ & $\begin{array}{c}93 \\
(55.0 \%)\end{array}$ \\
\hline Ownership of pets & $\begin{array}{c}70 \\
(54.7 \%)\end{array}$ & $\begin{array}{c}64 \\
(38.8 \%)\end{array}$ \\
\hline Exposure to car fumes & $\begin{array}{c}39 \\
(30.5 \%) \\
\end{array}$ & $\begin{array}{c}54 \\
(32.3 \%) \\
\end{array}$ \\
\hline $\begin{array}{l}\text { Presence of dampness in the } \\
\text { flat }\end{array}$ & $\begin{array}{c}17 \\
(13.3 \%)\end{array}$ & $\begin{array}{c}28 \\
(16.8 \%)\end{array}$ \\
\hline
\end{tabular}

*total number of children from studied control population, ${ }^{* *}$ total number of children from studied exposed population. 
Table 4. Characteristics of adults (20-65 years) in the study population.

\begin{tabular}{|c|c|c|}
\hline Characteristic & $\begin{array}{l}\text { Control } \\
\left(n^{*}=374\right)\end{array}$ & $\begin{array}{l}\text { Exposed } \\
\left(\mathrm{n}^{* *}=417\right)\end{array}$ \\
\hline Male & $\begin{array}{c}167 \\
(44.7 \%)\end{array}$ & $\begin{array}{c}185 \\
(44.4 \%)\end{array}$ \\
\hline Female & $\begin{array}{c}207 \\
(55.3 \%)\end{array}$ & $\begin{array}{c}232 \\
(55.6 \%)\end{array}$ \\
\hline $\begin{array}{c}\text { Age } \\
\text { 20-34 years }\end{array}$ & $\begin{array}{c}110 \\
(21.9 \%)\end{array}$ & $\begin{array}{c}160 \\
(27.3 \%)\end{array}$ \\
\hline $35-49$ years & $\begin{array}{c}124 \\
(24.7 \%)\end{array}$ & $\begin{array}{c}126 \\
(21.5 \%)\end{array}$ \\
\hline 50-65 years & $\begin{array}{c}140 \\
(27.9 \%)\end{array}$ & $\begin{array}{c}131 \\
(22.4 \%)\end{array}$ \\
\hline $\begin{array}{c}\text { Education } \\
\text { Primary school }\end{array}$ & $\begin{array}{c}374 \\
(100.0 \%)\end{array}$ & $\begin{array}{c}417 \\
(100.0 \%)\end{array}$ \\
\hline Gymnasium & $\begin{array}{c}23 \\
(6.5 \%) \\
\end{array}$ & $\begin{array}{c}27 \\
(8.6 \%) \\
\end{array}$ \\
\hline Basic vocational school & $\begin{array}{c}134 \\
(38.0 \%)\end{array}$ & $\begin{array}{c}150 \\
(38.3 \%)\end{array}$ \\
\hline Secondary school & $\begin{array}{c}272 \\
(76.4 \%) \\
\end{array}$ & $\begin{array}{c}302 \\
(76.3 \%) \\
\end{array}$ \\
\hline College & $\begin{array}{c}158 \\
(44.6 \%) \\
\end{array}$ & $\begin{array}{c}161 \\
(42.7 \%) \\
\end{array}$ \\
\hline Heating (central heating) & $\begin{array}{c}248 \\
(66.3 \%)\end{array}$ & $\begin{array}{c}411 \\
(98.6 \%)\end{array}$ \\
\hline Using a gas stove & $\begin{array}{c}309 \\
(82.6 \%)\end{array}$ & $\begin{array}{c}298 \\
(71.5 \%)\end{array}$ \\
\hline Ownership of pets & $\begin{array}{c}220 \\
(58.8 \%)\end{array}$ & $\begin{array}{c}152 \\
(36.5 \%)\end{array}$ \\
\hline Exposure to car fumes & $\begin{array}{c}133 \\
(35.6 \%)\end{array}$ & $\begin{array}{c}147 \\
(35.3 \%)\end{array}$ \\
\hline $\begin{array}{l}\text { Presence of dampness in } \\
\text { the flat }\end{array}$ & $\begin{array}{c}32 \\
(8.6 \%)\end{array}$ & $\begin{array}{c}46 \\
(11.0 \%)\end{array}$ \\
\hline
\end{tabular}

"total number of adults from studied control population, ${ }^{* *}$ total number of children from studied exposed population.

\section{Group Division: Control vs. Exposed}

In the municipality directly adjacent to the wastewater treatment plant we found an increased incidence of respiratory diseases compared to the control population (Figs 2a, b). Among both children and adults belonging to the exposed group the following symptoms (confirmed by medical diagnosis; Fig. 2a) occur significantly more often than in the control group: frequent colds, recurrent respiratory tract infections, throat irritation, dyspnoea, recurrent rhinitis, and nasal irritation/burning sensation.

Compared to their peers from outside the impact area, the exposed children showed a higher incidence of respiratory ailments: recurrent sinusitis and chronic cough. Also, compared to the control group, bronchial asthma was found significantly more often in the group of adults living in the area adjacent to the wastewater treatment plant.
Similar results were obtained in the case of the symptoms reported as independent opinion of the respondent (Fig. 2b). Only among children did frequent colds and recurrent respiratory tract infections occur more often in the control group than in the exposed group.

The questionnaire also contained questions related to diseases such as chronic bronchitis, chronic sinusitis, disorders of smell, and other respiratory diseases. However, we did not notice significant differences in their occurrence between studied populations.

\section{Zone Division: A, B, C}

Zone division of the two populations allowed for analysis of the dependence of the occurrence of respiratory diseases on the distance from the wastewater treatment plant. When the distance increased, the incidence of reported disorders (confirmed by medical diagnosis) in the analyzed age groups decreased (Fig. 3a). Among children, significant differences in the incidence of disorders of the respiratory system between the compared zones concerned: frequent colds, recurrent respiratory infections, chronic bronchitis, recurrent sinusitis, throat irritation, chronic cough, shortness of breath, recurrent rhinitis, nasal irritation/burning sensation in the nose, disorders of smell, and other respiratory diseases. In adults, the greatest differences in the incidence of reported ailments concerned: frequent colds, recurrent respiratory infections, bronchial asthma, throat irritation, recurrent rhinitis, nasal irritation/burning sensation, and disorders
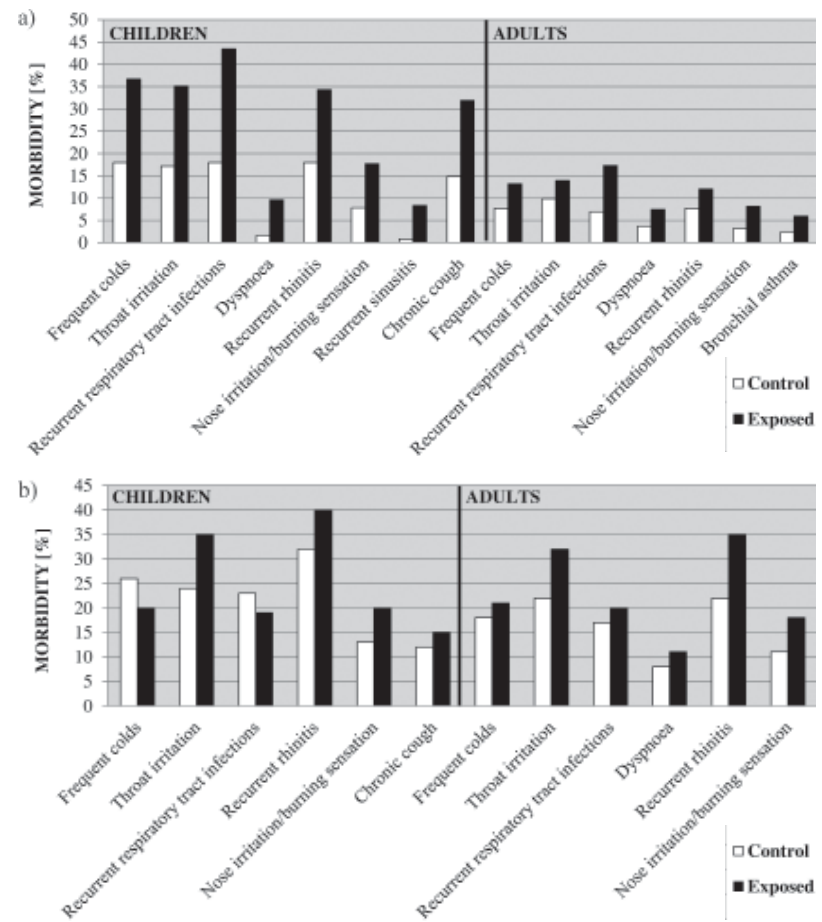

Fig. 2. Statistically significant differences of reported disorders of the respiratory system in children and adults between the control and exposed groups (a) is "Yes (doctor's opinion)", b) is "Yes (respondent's opinion)"). 

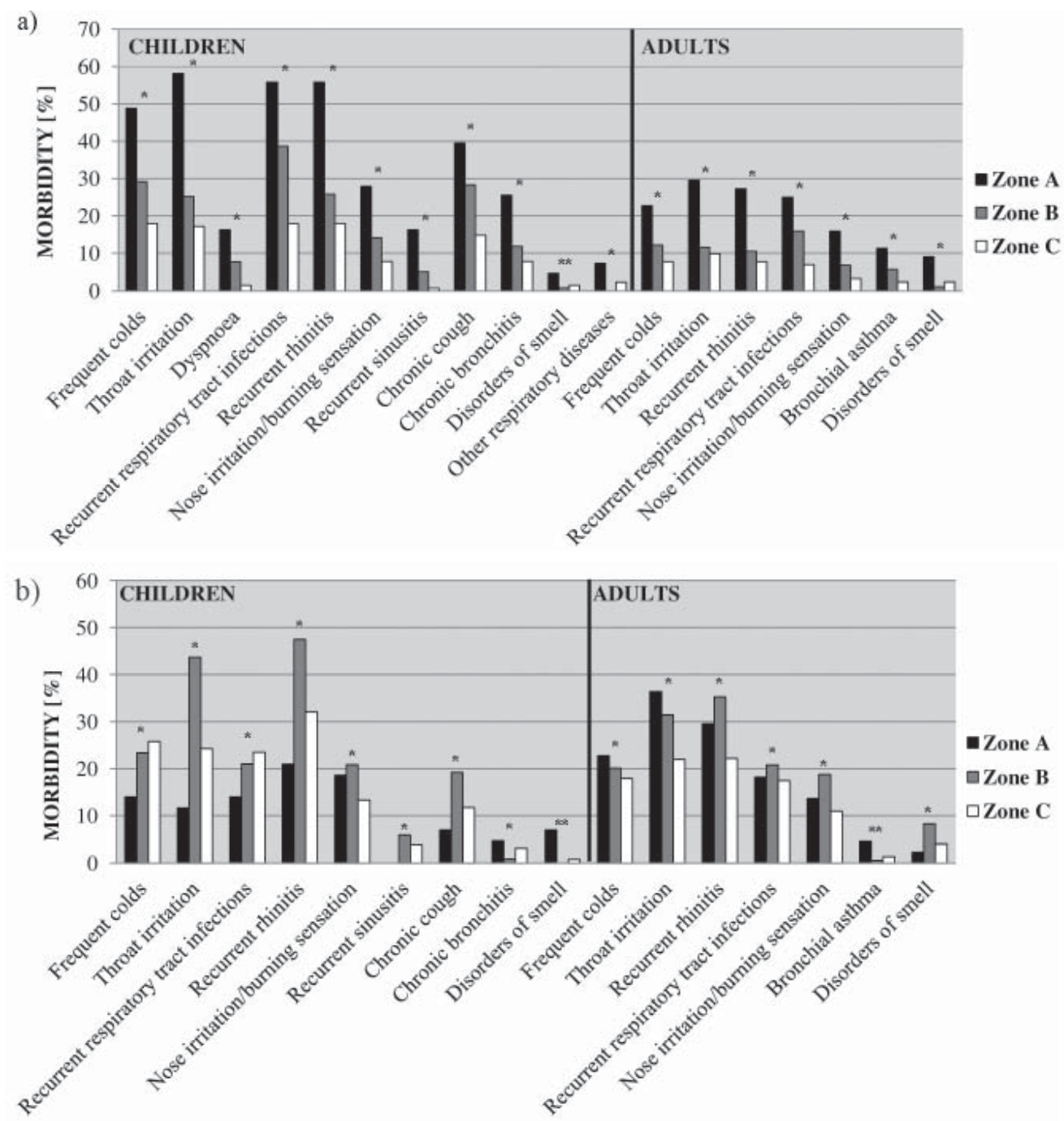

Fig. 3. Statistically significant differences of reported disorders of the respiratory system in children and adults depending on the distance from the wastewater treatment plant (by distance zone) (A is "Yes (doctor's opinion)", B is "Yes (respondent's opinion)"); (*zone A vs. zone $\mathrm{B}$ vs. zone $\mathrm{C}$ marked as, ${ }^{* *}$ zone $\mathrm{A}$ vs. zone $\mathrm{B}$ and zone A vs. zone $\mathrm{C}$ marked).

a)

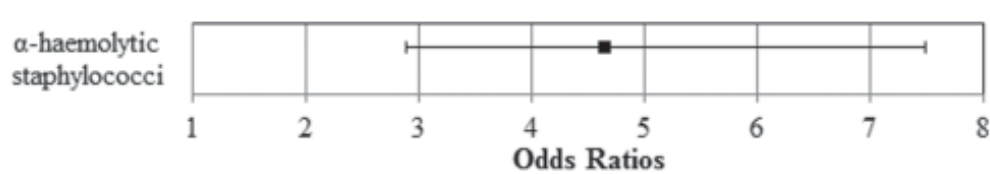

b) $\beta$-haemolytic
staphylococci

c)

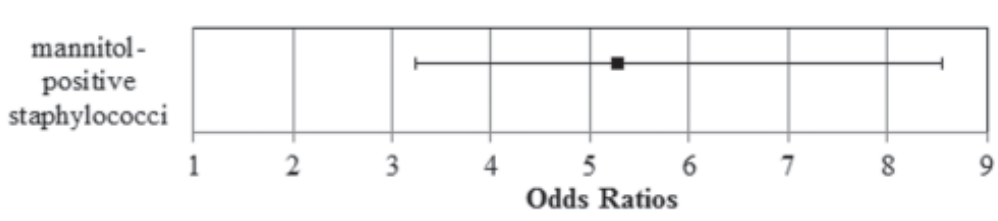

\section{OR $(95 \%$ CI $)$}

4.65 (2.89-7.47)

OR $(95 \% \mathrm{CI})$

5.39 (1.33-21.87)

OR $(95 \% \mathrm{CI})$

5.27 (3.24-8.55)

Fig. 4. Odds ratios (OR) and 95\% confidence intervals (CI) for respiratory system symptoms (in zones A and C) relative to individual microorganisms ( $\mathrm{A}$ is $\alpha$-haemolytic staphylococci, $\mathrm{B}$ is $\beta$-haemolytic staphylococci, and $\mathrm{C}$ is mannitol-positive staphylococci; all presented data: $\mathrm{p}<0.05)$. 
a)

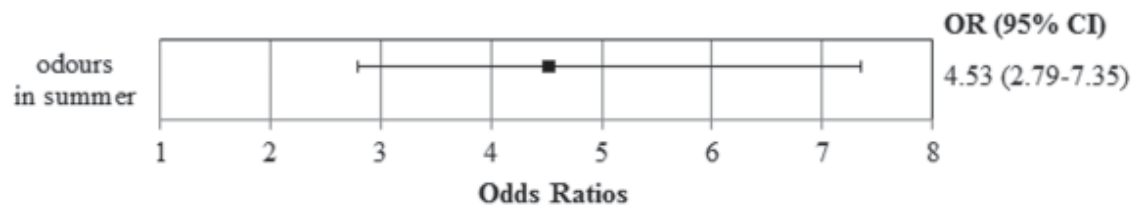

OR $(95 \% \mathrm{CI})$

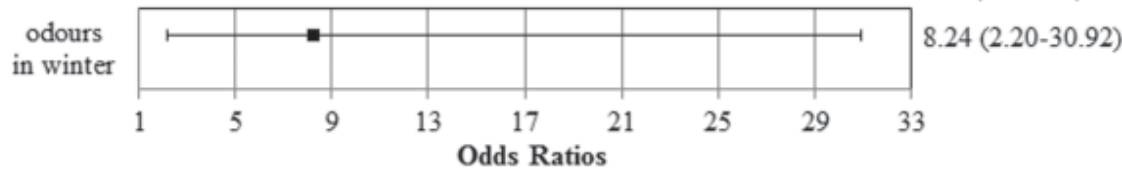

b)

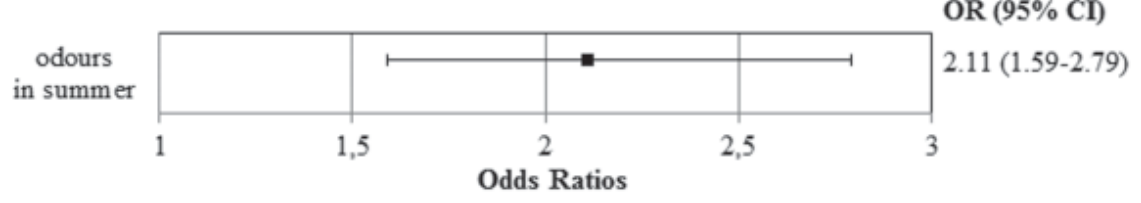

Fig. 5. Odds ratios (OR) and $95 \%$ confidence intervals $(\mathrm{CI})$ for respiratory system symptoms (A in zone A and C: in summer and in winter; $\mathrm{B}$ in zone $\mathrm{B}$ and $\mathrm{C}$ : in summer) relative to odours; all presented data: $\mathrm{p}<0.05$.

of smell. In both children and adults, respiratory diseases are reported most often in people living in the immediate vicinity of the wastewater plant (in zone A) and decrease as the distance from the plant increases. Only in the case of smell disorders (in children and adults) and other respiratory diseases (in children) was there no regular decrease.

The majority of symptoms reported as independent opinions of the respondent (Fig. 3b) predominated in the intermediate zone (zone B) among children: throat irritation, recurrent rhinitis, nose irritation/burning sensation, recurrent sinusitis, and chronic cough; and among adults: recurrent rhinitis, recurrent respiratory tract infections, nose irritation/burning sensation, disorders of smell.

\section{Analysis of the Impact of Air Pollution on the Incidence of Respiratory System Disorders}

Symptoms of the respiratory system were compared between residents exposed to air pollutants emitted from the wastewater treatment plant (concentrations of microorganisms exceeding Polish standards; odours) and the control group, which was outside the impact area of the plant.

No significant influence of microorganisms commonly found in the environment (actinomycetes, psychrofilic and mesofilic bacteria, moulds - mostly low or medium levels of air pollution) on the respiratory system of nearby residents, in contrast to pathogenic staphylococci (high levels of air pollution): $\alpha$-haemolitic staphylococci, $\beta$-haemolitic staphylococci, and mannitol-positive staphylococci (Figs 4a-c).

Both among the inhabitants of the immediate vicinity of the wastewater treatment plant (zone A) as well in the intermediate zone (zone B) was the relationship between reported symptoms of respiratory system and exposure to odours emitted from the plant demonstrated (in zone A compared to the control group - in summer and in winter: Fig. 5a); in zone B compared to the control group - only in summer: Fig. 5b).

Risk Factors for Respiratory System Symptoms Among the Respondents - Regression Analysis

The aim of this analysis was to demonstrate whether other coexisting, potential health risk factors also impacted the occurrence of respiratory system symptoms (Fig. 6).

Among those, the greatest risk of illness was associated with residences in blocks of flats and exposure to odours. In addition, the longer the period of residence in the neighborhood of the wastewater treatment plant and the younger the respondents, the more often they reported respiratory disorders. By contrast, the presence of pets in a home appeared to have a protective effect (people without pets suffered from diseases significantly more often than pet owners $\mathrm{OR}<1$ ).

Risk factors for respiratory system symptoms among residents in the immediate vicinity of the wastewater treatment plant - regression analysis.

In this model, we compared the incidence of the respiratory system symptoms only between the residents in the immediate vicinity of the wastewater treatment plant (zone A) and the control group (Fig. 7).

Analysis shows that respiratory system diseases most commonly occurred in people exposed to odours and high concentrations of bacteria. The risk of these disorders was also greater among the residents of the block of flats than the residents of other types of buildings, among people living longer in the vicinity of the wastewater treatment plant than new residents, and also among younger than older people. 


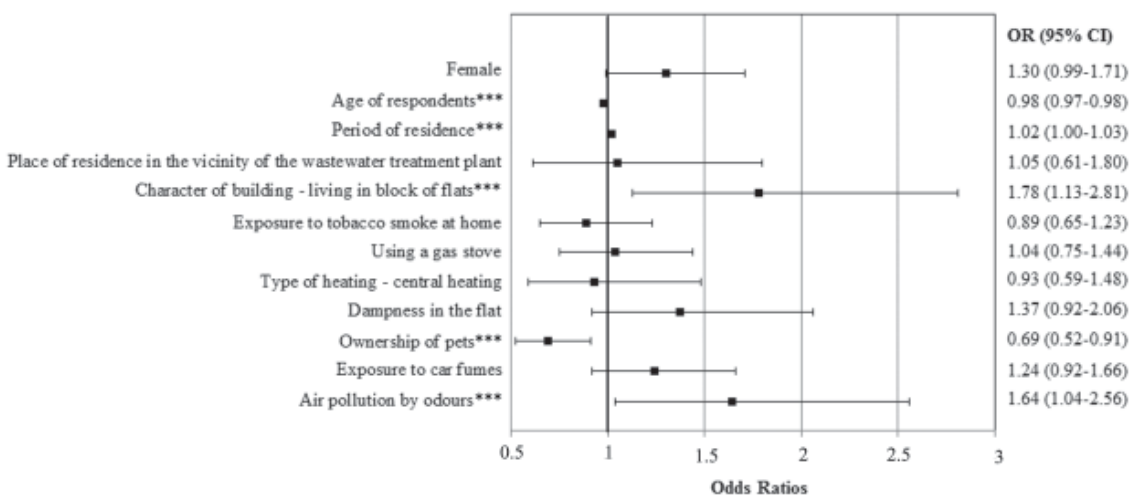

Fig. 6. Odds ratios (OR) and $95 \%$ confidence intervals $(\mathrm{CI})$ for respiratory system symptoms relative to the risk factors $\left(\mathrm{n}^{*}=1088\right)$; $\mathrm{R}_{\text {Nagelkerke'a }}{ }^{* *}=0.12$; ("all respondents from studied population, ${ }^{* *}$ generalized coefficient of determination, ${ }^{* * *} \mathrm{p}<0.05$ ).

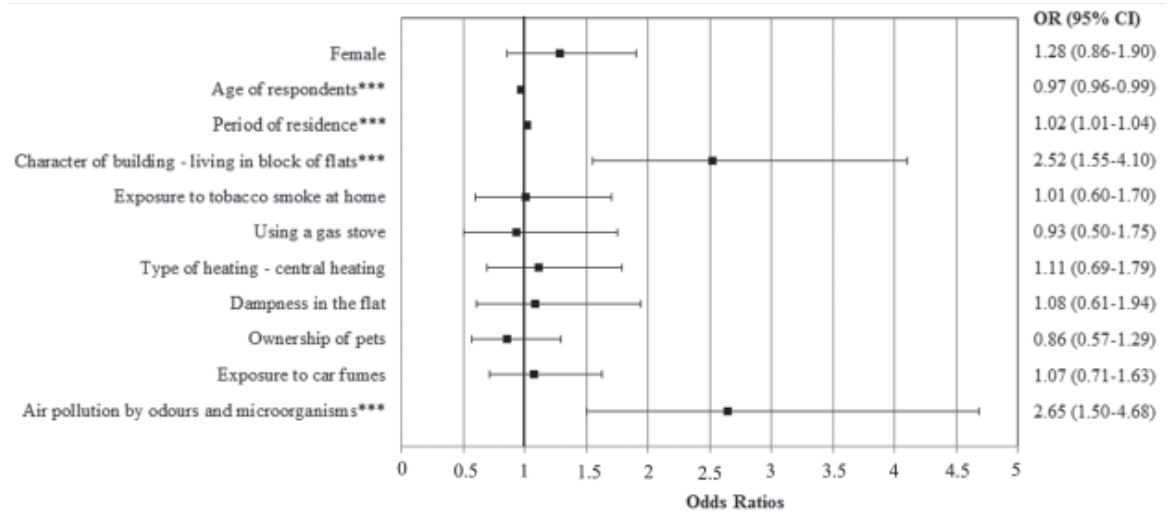

Fig. 7. Odds ratios (OR) and $95 \%$ confidence intervals $(\mathrm{CI})$ for respiratory system symptoms (in zones $\mathrm{A}$ and $\mathrm{C}$ ) relative to the risk factors $\left(\mathrm{n}^{*}=589\right) ; \mathrm{R}^{2}{ }_{\text {Nagelkerke'a }}{ }^{* * *}=0.13$. ("number of people from zones A and $\mathrm{C},{ }^{* *}$ generalized coefficient of determination, $\left.{ }^{* * *} \mathrm{p}<0.05\right)$.

\section{Discussion}

Not many papers deal with the issue of the impact of wastewater or wastewater sludge on the health of nearby residents. Typically, results are drawn from a health survey of occupationally exposed employees of wastewater treatment plants and composting plants [3-7]. The reported disease symptoms are often associated with odour nuisance caused by odour emissions $[8,15]$. The most frequently reported conditions include respiratory disorders $[5,8-9,15]$.

In the presented studies we observed significant differences between the exposed group and the control group in the incidence of reported colds, recurrent respiratory infections, throat irritations, dyspnoea, recurrent rhinitis, and nasal irritation/burning sensation. There was also a visible correlation between these symptoms and distance from the treatment plant. The incidence of reported respiratory disorders decreased gradually with increased distance from the treatment plant. By contrast, the majority of symptoms reported as independent opinion of the respondent predominated in the intermediate zone, which could be caused by the fact that residents in the intermediate zone and persons belonging to the control group less frequently consulted with their doctor than residents of the nearest neighborhood of the wastewater treatment plant. Perhaps their health problems were not as severe and did not require medical intervention.

Neither respondents nor the reviewers knew the zone classification because zoning by exposure intensity was made later, after collecting all questionnaires, based on the results of environmental studies conducted at the same time. Therefore, the provided answers were not biased.

Similar research both in terms of population size $(\mathrm{N}=1,142)$ and health disorders was carried out by Aatamila et al. [8]. They analysed the relationship between disease symptoms and the distance and olfactory perception (and irritability) of the odours emitted from a wastewater treatment plant. However, in their case the results did not confirm dependence of the declared health disturbances on distance from the plants. The authors assumed that this was due to the existence of significant technological differences between the analyzed wastewater treatment plants. In their case, the only statistically significant results concerned nasal irritation/nasal congestion (as in our studies), hoarseness/ dry throat, and cough with phlegm. 
By contrast, the results of studies conducted by German researchers [9] confirmed the existence of a distance relationship. They investigated the health effects of exposure to bioaerosols among people living in the vicinity of a composting plant. They demonstrated the influence of high levels of bacteria in the air on the incidence of respiratory ailments up to $0.55 \mathrm{~km}$ from the plant. In this case the obtained results were independent of the reported olfactory irritability. The data are consistent with the results of our research. They also noticed an association between high levels of bacteria in the air and reported ailments of the respiratory system by residents in the immediate vicinity of the wastewater treatment plant (up to $0.5 \mathrm{~km}$ ). According to Herr et al. [15-16], the respiratory ailments occur primarily due to microbiological air pollution (exposure solely to odour does not cause health disorders). Other authors (including Khuder et al. [17]) explained the increase in the number of reported diseases in the presence of a noticeable, irritating odour as anxiety (psychosomatic) responses of people afraid of poisoning.

However, presented research shows that both microbiological and odorous air pollution has a negative effect on the respiratory system of local residents. Simultaneous exposure to odours and high concentrations of bacteria increased the risk for ailments of the respiratory system more than two times among the residents of zone A as compared to the control group. Exposure to odours not only in the immediate vicinity of the wastewater treatment plant caused the occurrence of respiratory disorders, and such dependence was also noted in the intermediate zone (in the summer). This is consistent with Finnish research [8] that showed the relationship between the declared disease symptoms and odour nuisance; especially in the case of: shortness of breath, hoarseness/dry throat $(\mathrm{OR}=1.5)$, and for other respiratory disorders $(\mathrm{OR}>1)$.

We observed that the exposed respondents frequently reported throat irritations, which can be caused by the impact of odours containing especially irritating chemicals, e.g., ammonia, hydrogen sulfide, and volatile organic compounds (VOCs) [18]. They stimulate the trigeminal nerve (which has three major branches in the mouth, nose, and eyes), which is perceived as an irritation [19]. The same explanation may apply to rhinitis and irritation of the nose, which is the major route of odour inhalation [8].

The bacteria that had a significant impact as reported by respondent symptoms were $\alpha$ - and $\beta$-haemolytic staphylococci and mannitol-positive staphylococci. They can be the cause of infections in both the upper and lower respiratory tracts. Colonization of the lower respiratory tract, e.g., mucous membrane of the trachea and bronchi, can cause acute symptoms, e.g., tracheitis, bronchitis, or pneumonia [20-21]. However, these diseases did not dominate in the vicinity of the studied wastewater treatment plant.

While long-term exposure to high concentrations of staphylococci in the air can cause such recurrent inflammatory symptoms as recurrent rhinitis and recurrent respiratory tract infections, it should be emphasized that these symptoms were significantly more frequent among people living in the vicinity of the wastewater treatment plant than in the control group.

Occupational exposure of the employees of wastewater treatment and composting plants determines similar disorders of the respiratory system as in the case of nearby residents. The results of studies conducted by Indian researchers indicate a significant increase in respiratory disorders (cough, dyspnoea, bronchitis, tightness in the chest) among the exposed employees compared with controls [22]. In a paper published by Rylander [5], this type of disorder is explained by exposure to endotoxins in bioaerosols and organic dust. The high probability of such a relationship is evidenced by the results of studies conducted by Heldal et al. [4]. Work-related symptoms were associated with exposure to endotoxins (ORs: 1.8-9.3 for a 10-fold increase in exposure levels). Endotoxins are introduced into the body by inhalation and initiate the release of inflammatory mediators, which then cross the blood-brain barrier [5]. Chronic exposure to high concentrations of endotoxins in the air may lead to a toxic effect (chronic bronchitis, toxic pneumonia) and a decline in lung function [5-6]. According to the available literature and research conducted by the authors, the residents generally did not complain of chronic respiratory symptoms (except for asthma), which can be explained by the lower exposure of the local population compared to the exposure of employees [8-9, 15-16]. Aatamila et al. [8] also suggest that there is a different mechanism of pathology in both groups (occupationally and residentially exposed).

While analysing the impact of the wastewater treatment plant on the respiratory tract of nearby residents, we also took into account the so-called risk factors. Increased risk of disease, apart from exposure to odours emitted from the wastewater treatment plant, was also associated with residence in multi-family housing (blocks of flats). A small space can accumulate air pollution (different gases, e.g., carbon dioxide and nitrogen dioxide) faster than single-family homes. Confirmation of this can be found in research conducted by Belanger et al. [23-24], which showed an association between the prevalence of asthma symptoms and residence in multi-family houses, where air pollution levels were much higher than in singlefamily homes.

Presented research also shows that the risk of respiratory system symptoms decreased with increasing age of the respondents. In our research we noticed a greater number of respiratory diseases in children than in adults from the exposed group, which can be explained by their less developed immunological system [25]. The group of children analysed by us (3 to 10-years old) had not yet reached full immunological maturity of the body.

On the other hand, only among adults (in contrast to children) did we notice significant differences in the incidence of bronchial asthma between the analyzed populations (the exposed group $6.0 \%$, the control group 
$2.4 \%$ ), which may be due to much longer exposure to pollutants (including allergens) coming from the wastewater treatment plant in the case of adults than in the case of children. Inflammatory processes may have been initiated in the airways, resulting in manifestation or intensification of disease symptoms in some people [2627].

The occurrence of respiratory diseases was also closely associated with the period of residence in the area of the wastewater treatment plant. The longer this time was, the greater the risk of respiratory diseases. This is undoubtedly the result of prolonged exposure to pollutants emitted from the plant. German researchers [15] obtained similar results, according to which a period of residence in the neighbourhood of a composting site more than five years increased the risk of frequent colds, bronchitis, coughing, and wheezing.

Analysis of the collected material demonstrated the protective role of keeping pets at home $(\mathrm{OR}<1)$ with respect to the reported respiratory ailments. A similar conclusion was reached, among others, by scientists who studied the incidence of respiratory diseases among Palestinian farmers [28]. A review of the literature made by Tse and Horner [29] showed a lower incidence of allergies among children who were brought up close to domestic animals. This confirms the theory that exposure to less hygienic conditions due to the presence of animals protects the body against allergic ailments (proper development of the immune system) [30-31].

\section{Conclusions}

The results of our study showed that, in accordance with microbiological and olfactometric measurements, the area of largest impact of the wastewater treatment plant on the health of residents reached up to $0.5 \mathrm{~km}$ from the plant (zone A) but was also noticeable above this distance (in zone B) - depending on meteorological conditions. Based on analysis of the health survey it was concluded that the incidence of respiratory ailments was greater in the impact area of the wastewater treatment plant compared to the control group, and decreased with the increase in that distance. The obtained results allow us to conclude that the emission of pollutants from the wastewater treatment plant has a significant negative impact on the respiratory tract of nearby residents (particularly children) and appropriate corrective actions should be taken. The results of this study and literature reports also demonstrate that wastewater treatment plants should not be located within $0.5 \mathrm{~km}$ of residential buildings due to their adverse health effects.

\section{Acknowledgements}

The study was funded by the Wroclaw University of Technology as commissioned by the Faculty of Environmental Engineering (No. 60-039-2). We thank the Faculty of Environmental Engineering for data on pollutants emitted from the studied wastewater treatment plant. We also wish to thank residents for their participation in the study.

\section{References}

1. KORZENIEWSKA E. Emission of bacteria and fungi in the air from wastewater treatment plants - a review. Front Biosci., 3, 393, 2011.

2. THOMAS R.J. Particle size and pathogenicity in the respiratory tract. Virulence, $\mathbf{4}(8), 847,2013$.

3. AL-BATANONY M.A., EL-SHAFIE M.K. Work-Related Health Effects among Wastewater Treatment Plants Workers. Int. J. Occup. Environ. Med., 2 (4), 237, 2011.

4. HELDAL K.K., MADS $\varnothing$ L., HUSER P.O., EDUARD W. Exposure, symptoms and airway inflammation among sewage workers. Ann. Agric. Environ. Med., 17 (2), 263, 2010.

5. RYLANDER R. Health effects among workers in sewage treatment plants. Occup. Environ. Med., 56 (5), 354, 1999.

6. HELDAL K.K., MADSØ L., EDUARD W. Airway inflammation among compost workers exposed to actinomycetes spores. Ann. Agric. Environ. Med. 22 (2), 253, 2015

7. VAN KAMPEN V., HOFFMEYER F., DECKERT A., KENDZIA B., CASJENS S., NEUMANN H.D., BUXTRUP M., WILLER E., FELTEN C., SCHÖHEICH R., BRÜNING T., RAULF M., BÜNGER J. Effects of bioaerosol exposure on respiratory health-in compost workers: a 13-year follow-up study. Occup. Environ. Med., 0, 1, 2016. [Epub ahead of print]

8. AATAMILA M., VERKASALO P.K., KORHONEN M.J., SUOMINEN A.L., HIRVONEN M.R., VILUKSELA M.K., NEVALAINEN A. Odour annoyance and physical symptoms among residents living near waste treatment centres. Environ. Res., 111 (1), 164, 2011.

9. HERR C.E.W., ZUR NIEDEN A., JANKOFSKY M., STILIANAKIS N.I., BOEDEKER R.H., EIKMANN T.F. Effects of bioaerosol polluted outdoor air on airways of residents: a cross sectional study. Occup. Environ. Med., 60 (5), 336, 2003.

10. JAREMKÓW A., SZAŁATA Ł., KOŁWZAN B., SÓWKA I., ZWOŹDZIAK J., PAWLAS K. Impact of a sewage treatment plant on the health of local residents: Gastrointestinal system symptoms. Pol. J. Environ. Stud., 26 (1), 127, 2017.

11. ZŁOTKOWSKA R., JAŹWIEC-KANYION B., KRUŻELMENDREK J., ZEJDA J. Air pollution and respiratory health in children, results of a PHARE-CESAR study in Poland. Proceedings of the Latvian Academy of Sciences, 52 (Supl.), 172, 1998.

12. POLISH STANDARDS PN-89/Z-04111/02. Air purity protection. Microbiological testings. Determination number of bacteria in atmospheric air (imision) with sampling by aspiration and sedimentation method (Ochrona czystości powietrza. Badania mikrobiologiczne. Oznaczanie liczby bakterii w powietrzu atmosferycznym (imisja) przy pobieraniu próbek metodą aspiracyjną i sedymentacyjną), Polski Komitet Normalizacji, Miar i Jakości, Warsaw, Poland, 1989 [In Polish].

13. POLISH STANDARDS PN-89/Z-04111/03. Air purity protection. Microbiological testings. Determination number of the fungi in the atmospheric air (imision) with sampling 
by aspiration and sedimentation method (Ochrona czystości powietrza. Badania mikrobiologiczne. Oznaczanie liczby grzybów mikroskopowych w powietrzu atmosferycznym (imisja) przy pobieraniu próbek metodą aspiracyjną i sedymentacyjną), Polski Komitet Normalizacji, Miar i Jakości, Warsaw, Poland, 1989 [In Polish].

14. MERRILL R.M. Introduction to epidemiology, $5^{\text {th }}$ ed., Chapter 7: Design strategies and statistical methods in analytic epidemiology; Chapter 9: Causal inference. Sudbury, Mass.: Jones and Bartlett Publishers, 2010.

15. HERR C.E.W., ZUR NIEDEN A., BÖDEKER R.H., GIELER U., EIKMANN T.F. Ranking and frequency of somatic symptoms in residents near composting sites with odor annoyance. Int. J. Hyg. Environ. Health., 206 (1), 61, 2003.

16. HERR C.E.W., ZUR NIEDEN A., KOPKA I., RETHAGE T., GIELER U., EIKMANN T.F., STILIANAKIS N.I. 2009 Assessment of somatic complaints in environmental health. Int. J. Hyg. Environ. Health., 212 (1), 27, 2009.

17. KHUDER S., MILZ S.A., BISESI M., VINCENT R., MCNULTY W., CZAJKOWSKI K. Health survey of residents living near farm fields permitted to receive biosolids. Arch. Environ. Occup. Health, 62 (1), 5, 2007.

18. JEON E.C., SON H.K., SA J.H. Emission characteristics and factors of selected odorous compounds at a wastewater treatment plant. Sensors, 9 (1), 311, 2009.

19. CLAESON A.S., LIDÉN E., NORDIN M., NORDIN S. The role of perceived pollution and health risk perception in annoyance and health symptoms: a population-based study of odorous air pollution. Int. Arch. Occup. Environ. Health., 86 (3), 367, 2013.

20. BOSCH A.A., BIESBROEK G., TRZCINSKI K., SANDERS E.A., BOGAERT D. Viral and bacterial interactions in the upper respiratory tract. PLoS Pathog., 9 (1), 1003057, 2013.

21. ZHOU Y., LIN P., LI Q., HAN L., ZHENG H., WEI Y., CUI Z., NI Y., GUO X. Analysis of the microbiota of sputum samples from patients with lower respiratory tract infections. Acta Biochim. Biophys. Sin., 42 (10), 754, 2010.

22. GIRI P.A., KASBE A.M., ARAS R.Y. A Study on Morbidity Profile of Sewage Workers in Mumbai City. International Journal of Collaborative Research on Internal Medicine \& Public Health, 2 (12), 450, 2010.
23. BELANGER K., GENT J.F., TRICHE E.W., BRACKEN M.B., LEADERER B.P. Association of indoor nitrogen dioxide exposure with respiratory symptoms in children with asthma. Am. J. Respir. Crit. Care Med.,173 (3), 297, 2006.

24. BELANGER K., HOLFORD T.R., GENT J.F., HILL M.E., KEZIK J.M., LEADERER B.P. Household levels of nitrogen dioxide and pediatric asthma severity. Epidemiology. 24 (2), 320, 2013.

25. SIMON A.K., HOLLANDER G.A, MCMICHAEL A. Evolution of the immune system in-humans from infancy to old age. Proc. Biol. Sci. 282 (1821), 20143085, 2015.

26. PEDEN D., REED C.E. Environmental and occupational allergies. J. Allergy Clin. Immunol. 125 (2 Suppl 2), 150, 2010.

27. ANDERSEN Z.J., BØNNELYKKE K., HVIDBERG M., JENSEN S.S., KETZEL M., LOFT S., SØRENSEN M., TJØNNELAND A., OVERVAD K., RAASCHOUNIELSEN O. Long-term exposure to air pollution and asthma hospitalisations in older adults: a cohort study. Thorax. 67 (1), 6, 2012.

28. ABU SHAM'A F., SKOGSTAD M., NIJEM K., BJERTNESS E., KRISTENSEN P. Lung function and respiratory symptoms in male Palestinian farmers. Arch. Environ. Occup. Health, 65 (4), 191, 2010.

29. TSE K., HORNER A.A. Allergen tolerance versus the allergic march: the hygiene hypothesis revisited. Curr. Allergy Asthma Rep., 8 (6), 475, 2008.

30. AZADM.B., KONYA T., MAUGHANH., GUTTMAND.S., SEARS M.R., BECKER A.B., SCOTT J.A., KOZYRSKYJ A.L., THE CHILD STUDY INVESTIGATORS. The Gut Microbiome and the Hygiene Hypothesis of Allergic Disease. Impact of Pets and Siblings on Infant Gut Microbiota, Annals of the American Thoracic Society, 11 (Suppl 1), 73, 2014.

31. KRAMER A., BEKESCHUS S., BRÖKER B.M., SCHLEIBINGER H., RAZAVI B., ASSADIAN O. Maintaining health by balancing microbial exposure and prevention of infection: the hygiene hypothesis versus the hypothesis of early immune challenge. J. Hosp. Infect., 83 (Suppl 1), 29, 2013. 